\title{
Influence of Resources on Academic Performance in Public Primary Schools in Manga Sub-County, Nyamira County, Kenya
}

\author{
Nyakeoga Agasa Erick, Christopher Ayienda \\ Department of Education Administration and Planning ,Mt. Kenya University, \\ P.O box 342-0100, Thika, Kenya \\ Corresponding author : enyakeoga@yahoo.com
}

\begin{abstract}
The study aimed at establishing the influence of physical resources, instructional resources, human resources on academic performance in public primary schools in Manga sub-county. The study employed a descriptive survey research design with a target population of 64 head teachers, 64 deputy head teachers and 475 assistant teachers and 1 DQASO. The study will help education stake holders in terms of policy formulation concerning adequacy of resources versus academic performance in public primary schools.
\end{abstract}

DOI: $10.7176 / \mathrm{JEP} / 13-4-04$

Publication date: February $28^{\text {th }} 2022$

\section{INTRODUCTION}

Teachers are educational inputs, and they are necessary for quality learning outcomes (Osei -Kofi 2005). The Kenyan vision 2030 recognizes human development as key pillar for an industrialising economy [Republic of Kenya, 2012]. However, Manga sub-county has recorded the lowest admission to National Schools with only $0.02 \%$ (Ministry of education, Manga sub-county 2017) with the total sub-county average mean of 227.61 , recording a continuous fail since 2014. In the year 2014, they recorded an average mean of 241.84, in 2015 an average mean of 238.06, in 2016 it was 239.09 and in 2017 a negative deviation of 11.48 . This has seen an outcry from the general public due to tremendous poor performance in public primary schools in Manga subcounty.

Despite the government funding of free primary education the government provides money to purchase teaching and learning materials, employing teachers and providing money for construction of classrooms through the stimulus program, there has been noted poor performance in most public primary schools In Manga sub-county. A number of factors influence the above /hence need for the study. The impact of resources on academic performance has not been adequately investigated and documented. The study seeks therefore to investigate and provide information on the influence of resources on academic performances in public primary schools in Manga sub-county. The study interrogated influence of physical resources, instructional resources, human resources and their influence on academic performance

\section{LITERATURE REVIEW}

The researcher used Education Production Function (E.P.F) theory from Thomas and Dreben (1980). The EPF theory states that education outcomes are a function of inputs to education process that are provided students, community, parents schools and education stakeholders. Schools inputs are most likely have an impact on the outputs.

The "Education Production Function Theory" perceives schools as enterprises in which raw materials ( students) and other inputs (teachers, time, books, play field, play materials and finances) are put together to produce certain outputs. At the same level, education is expensive and investment in education takes a substantial share of national resources in most countries.

An inadequate distribution of instructional resources exists between urban schools, mid-urban and rural schools with urban schools receiving the highest priority followed by mid-urban schools then rural schools. As result, the trend in performance in urban and mid-urban schools is better than rural schools.

The human resources in schools consist of teachers, students and the support staff. In a KIPPRA paper on cost reduction and financing options, it was observed that schools strive to be self -sufficient. (Ngware, 2007) explains that schools to be entrepreneurial fair of their staff and students in maximizing the returns to human and physical resources at their disposal. The hiring of human resources in the schools in terms of teachers is a prerogative of the state. Due to understaffing schools are compelled to mobilize resources to meet the teacher deficit.

Most physical facilities in the least developed countries are of much concerned. Parents may refuse to take their children to schools where sanitation facilities are of great concern. Some modern well equipped schools are lacking a permanent source of water, electricity, a school garden, a school canteen and a first aid kid. Over seventy percent of classrooms in several countries have either in-adequate ventilation and lighting. Parents take children to schools which need major repairs and in most countries one third of the pupils go to temporary 
schools more so in rural areas.

An inadequate distribution of instructional resources exists between urban schools, mid-urban and rural schools with urban schools receiving the highest priority followed by mid-urban schools then rural schools. As result, the trend in performance in urban and mid-urban schools is better than rural schools. Based on any fee payment to schools, the government is to provide all the teaching learning aids, teacher guides, chalks, dusters registers and internal examinations .(republic of Kenya, 2002)states that by 2009 it assumed that textbooks were enough in schools and so no further allocation for textbooks was done in 2010 and 2011 . The study seeks to find out if it is true that the textbooks are enough in primary schools in Manga sub-county.

In most of the developing countries, the PTR is worrying. It is estimated that over $84 \%$ of classrooms in developing countries had over 40 pupils per teacher states UNESCO (2006). (Ron ,2003) notes that the classroom conditions are particularly acute in number of developing countries where large class sizes often swell up and go beyond 100 pupils. The higher enrolment and lack of enough staffing compromising the quality of education and performance in National examinations.

The government had set a target by the year 2006 that the teacher-pupil ratio should be 1:40 but this has not yet been achieved due to the inconsistency with the current primary school staffing formulas of eight teachers for seven classes in urban schools.

\section{Methodology}

Research methodology Design.:a descriptive survey research design suggested by (Orodho,2002) was used as it allow researchers to gather information, summarise it, present and interpret for the purpose of clarification.

Study Area: the study was carried out in public primary schools in Manga sub-county, Nyamira County, Kenya. Manga sub-county borders Nyamira sub-county to the north, Masaba north, Marani and Kisii central subcounties. The sub-county covers approximately 6000 square kilometres. It covers Manga, Magombo and Kemera divisions. It also has four educational zones namely: Manga, Tombe, Kemera and Magombo. The sub-county has well drained fertile soils and rugged terrain which is dissected by valleys of which small rivers flow.

Population of the study: The population of the study consists of 64 head teachers, 64 deputy head teachers, 475 teachers and 1 QASO Manga sub-county. Therefore the total population for the study is 604 subjects.

Sampling procedures and Sample size:. Stratified, purpose and simple random sampling procedures were used at different levels of selection from the 64 schools 20 will be stratified to form a sample. Purposive sampling was used to get the DQASO. Random sampling was used to select assistant teachers and pupils. A total of 234sample studied

\section{Results and Discussion}

Performance of the public primary schools in Manga Sub-county for the last 6 years i.e. from 2013 to 2018. According to this question, teachers were supposed to give out the results so as to compare them for the last 6 years so that we can be able to know whether they are improving or not as according to the main object of the research. As shown below in the table below;

\begin{tabular}{|l|l|l|l|}
\hline YEAR & SCHOOL MEAN & $\begin{array}{l}\text { FREQUENCY } \\
\text { DISTRIBUTION }\end{array}$ & PERCENTAGES \\
\hline 2013 & 284.62 & 1 & 16.7 \\
\hline 2014 & 265.10 & 1 & 16.7 \\
\hline 2015 & 271.40 & 1 & 16.7 \\
\hline 2016 & 282.39 & 1 & 16.7 \\
\hline 2017 & 290.77 & 1 & 16.7 \\
\hline 2018 & 281.00 & 1 & 16.7 \\
\hline & & 6 & 100 \\
\hline
\end{tabular}

As from the results above, we can see that they experienced a drop in performance as from $\mathbf{2 8 4 . 6 2}$ as the mean in 2013 to 265.10. But they have been experiencing as positive deviation since 2014 to 2018 that is from $\mathbf{2 6 5 . 1 0}$ to $\mathbf{2 7 1 . 4 0}$ to $\mathbf{2 8 2 . 3 9}$ to $\mathbf{2 9 0 . 7 7}$, whereby they experienced are big positive deviation of $+\mathbf{8 . 3 3}$. This means most the teachers in this county are busy working on the best examination results and also most the schools have the required resources that makes them to perform well in the examinations. But still they registered a negative deviation in 2018 in that from $\mathbf{2 9 0 . 7 7}$ to $\mathbf{2 8 1 . 0 0}$ which was $\mathbf{- 9 . 7 7}$, show that something wrong happened while the pupils were preparing themselves towards the exams. But in general it shows that public schools in Manga Sub-county are in good hands of the teachers and also have the required resources that help to perform well.

\section{Physical and instructional resources}

This question was used mostly to determine whether the head teachers have both the physical resource and the instructional resource in their schools which has many effects to academic performance in Manga Sub-county, here are the results as shown in the table below; 


\begin{tabular}{|l|l|l|}
\hline RESPONSE & FREQUENCY DISTRIBUTION & PERCENTAGES \\
\hline Agree & 1 & 6.3 \\
\hline Neither agree & 1 & 6.3 \\
\hline Strongly disagree & 14 & 87.5 \\
\hline & 16 & 100 \\
\hline
\end{tabular}

The above reveals that most of the schools in Manga Sub-county lack this important resources with $87.5 \%$ which is too big thus the county government of Nyamira with the help of the office education something must be done to help improve academics of the pupils in primary schools in Manga Sub-county. According to the table above again you see that only one head teacher has such resources with $6.3 \%$, this means that without the government intervention some of the schools will not perform well.

Intergartion of ICT in teaching

The essence of this question was to establish whether during teaching do some school include the ICT skills here are the results in the table below;

\begin{tabular}{|l|l|l|}
\hline RESPONSE & FREQUENCY DISTRIBUTON & PERCENTAGES \\
\hline Strongly agree & 1 & 6.3 \\
\hline Agree & 3 & 18.3 \\
\hline Neither agree & 12 & 75.0 \\
\hline & 16 & 100 \\
\hline
\end{tabular}

According to the table results it clearly shows that most of the heads are not sure with such programmes in their school with $75 \%$ meaning that most schools lack such services hence not being able to equip their pupils with the required ICT skills. Only one of the heads is sure of such services in the school with $6.3 \%$ thus in terms of the instructional resources and physicals resources according to this question has to checked and be able to give a long lasting solution, whereby better results will be achieved.

There are challenges of innovation and creativity in integrating ICT and education in learning in my school.

Here are results of the challenges in the table below;

\begin{tabular}{|l|l|l|}
\hline RESPONSE & FREQUENCY DISTRIBUTION & PERCENTAGES \\
\hline Strongly agree & 12 & 75.0 \\
\hline Agree & 4 & 25.0 \\
\hline & 16 & 100 \\
\hline
\end{tabular}

From the above output we are able to notice that most of the head teachers strongly agree there are challenges in handling such matters in their primary schools with $75 \%$. Implying that according to the results in the table (1.6) meaning that most school are not able to access ICT services in their schools which brings a big challenge thus there is need to improve those resources to have ICT skilled pupils in future as according to the digitalism that is happening across the country, by so doing academic performance will be improve.

There are digital learning materials in my school.

The main of this question being, is there digital learning materials supply in all primary schools in Manga Subcounty? The results are as shown below in the table;

\begin{tabular}{|l|l|l|}
\hline RESPONSE & FREQUENCY DISTRIBUTION & PERCENTAGES \\
\hline Strongly agree & 12 & 75.0 \\
\hline Agree & 2 & 12.5 \\
\hline Neither agree & 1 & 6.3 \\
\hline Strongly disagree & 1 & 6.3 \\
\hline & 16 & 100 \\
\hline
\end{tabular}

As were refer to the results above in the table shows that most head teachers have tried to install digital learning materials with $75 \%$ which is a positive indication that there is no doubt in terms of academic performance, for those who not done it they have the opportunity to do it so as to be in the same level with those who done it.

In your own opinion, is professional development of teachers necessary in promoting better teaching outcome?

This means that, the aim was to establish whether professional development has some effects towards academic performance, thus here are the results according the research done in Manga Sub-county;

\begin{tabular}{|l|l|l|}
\hline OPTIONS & FREQUENCY DISTRIBUTION & PERCENTAGES \\
\hline Yes & 15 & 93.8 \\
\hline No & 1 & 6.3 \\
\hline & 16 & 100 \\
\hline
\end{tabular}

Hence according to the above table results means that $93.8 \%$ of head teachers they fully support that the professional development among the teachers brings about better outcome in the pupil's performance, means that 
all others teachers who not done professional development must do it so as to have better teaching outcome in the near future.

Number of classroom?

In terms of physical resources, the question was used to come the information so as to determine whether they are enough to all schools in Manga Sub-county as shown below in the table;

\begin{tabular}{|l|l|l|}
\hline NUMBER OF CLASSES & FREQUENCY DISTRIBUTION & PERCENTAGES \\
\hline 3 & 1 & 4.8 \\
\hline 8 & 1 & 4.8 \\
\hline 9 & 3 & 14.3 \\
\hline 10 & 4 & 19.0 \\
\hline 11 & 3 & 14.3 \\
\hline 12 & 1 & 4.8 \\
\hline 13 & 1 & 4.8 \\
\hline 14 & 2 & 9.5 \\
\hline 16 & 1 & 4.8 \\
\hline 17 & 1 & 4.8 \\
\hline 18 & 1 & 4.8 \\
\hline Aveage number of classroom is 12 & & \\
\hline
\end{tabular}

This show that most the primary schools in Manga Sub-county have at least the minimum number of classes in there, schools according to the head teachers' appendix but only 1 primary school that has 3 classes which is $4.8 \%$ but remaining have as many as 10 classes which $19.0 \%$ to 18 classes with $4.8 \%$. This means that, there should be no any doubt about performance since the classes are at least enough for the pupils but still for those who feel like the classes are not enough then they must add to the required number of classes according to the population in their schools. The average number of classroom in Manga is 12. Which is not adequate to accommodate all the students

latrine This question was all about the physical resources in terms of the latrines, as shown below;

\begin{tabular}{|l|l|l|}
\hline RESPONSE & FREQUENCY DISTRIBUTION & PERCENTAGES \\
\hline YES & 10 & 47.6 \\
\hline NO & 9 & 42.9 \\
\hline & 21 & 100 \\
\hline
\end{tabular}

This indicates that 10 head teachers said that they enough latrine which represents $47.6 \%$ and those heads who said that they do not enough latrine were 9 with $42.9 \%$ which is almost equal to those who say they have enough meaning that something must be done to increase that number of latrines so as all the pupils receives best services from those resources. By so doing the pupils will have enough time to study in class but if not they will continue queuing up so that services instead of being in class to attend to a lesson.

\section{Availability of a library}

The results were as shown below;

\begin{tabular}{|l|l|l|}
\hline RESPONSE & FREQUENCY DISTRIBUTION & PERCENTAGES \\
\hline Yes & 9 & 42.9 \\
\hline No & 12 & 57.1 \\
\hline & 21 & 100 \\
\hline
\end{tabular}

Meaning that most head teachers lack access to library services in their schools by response of no with 12 of them representing $57.1 \%$, but only 9 heads were those who said that they have library services that is $42.9 \%$, for better and quality academic performance the county government must invest in increasing the number of library services to all the primary school in Manga Sub-county.

Connection with electricity.

According to this question its aim was to see whether electricity services are available to some schools in Manga Sub-county as shown below;

\begin{tabular}{|l|l|l|}
\hline RESPONSE & FREQUENCY DISTRIBUTION & PERCENTAGES \\
\hline Yes & 20 & 95.2 \\
\hline No & 1 & 4.8 \\
\hline & 21 & 100 \\
\hline
\end{tabular}

Thus this results holds that almost all of the school heads have access to the electricity products with 20 of the heads thus this represents $95.2 \%$ hence this has a positive impact towards the academic performance. Thus this gives as an opportunity to give thanks to the government for its effort towards rural electricity connectivity across the country. 
Permanent source of water

\begin{tabular}{|l|l|l|}
\hline RESPONSE & FREQUENCY DISTRIBUTION & PERCENTAGES \\
\hline Yes & 5 & 23.8 \\
\hline No & 15 & 71.4 \\
\hline & 21 & 100 \\
\hline
\end{tabular}

This results shows that most primary schools in Manga Sub-county have not been able to have permanent water sources which represents $71.4 \%$ but only 5 heads have such resources which is $23.8 \%$, thus some programmes must be put in place to have sources resources in schools to have a better environment for better results in future.

\section{Playing fields}

\begin{tabular}{|l|l|l|}
\hline RESPONSE & FREQUENCY DISTRIBUTION & PERCENTAGES \\
\hline Yes & 10 & 47.6 \\
\hline No & 10 & 47.6 \\
\hline & 21 & 100 \\
\hline
\end{tabular}

According to the 20 head teachers who were able to respond 10 of them said they have the playing fields which is $47.6 \%$ and also 10 of them sad that they do not have the playing fields, thus for a better environment to be able to produce better results all primary school have to be provide with this type of the physical resource.

\section{Space for expansion}

This question was about to establish which schools have enough land for the expansion e.g. for more classes, offices, building of other playing fields etc., as shown below in the table;

\begin{tabular}{|l|l|l|}
\hline RESPONSE & FREQUENCY DISTRIBUTION & PERCENTAGES \\
\hline Yes & 13 & 61.9 \\
\hline No & 7 & 33.3 \\
\hline & 21 & 100 \\
\hline
\end{tabular}

As per the results above in the table it indicates that 13 head teachers have room for expansion which represents $61.9 \%$ and 7 of them say that they have no room for expansion this means that most school can be expanded $\mathrm{id}=\mathrm{f}$ there is need to do so.

Availability of writing materials

\begin{tabular}{|l|l|l|}
\hline OPTIONS & FREQUENCY DISTRIBUTION & PERCENTAGES \\
\hline Yes & 16 & 76.2 \\
\hline No & 5 & 23.8 \\
\hline & 16 & 100 \\
\hline
\end{tabular}

Due the free education system primary school started by Hr. Mwai Kibaki thus this has helped most head teachers to have writing materials in their schools that is 16 of them which $76.2 \%$, but still other school do not have enough of such resources with $23.8 \%$.

Enough teachers

\begin{tabular}{|l|l|l|}
\hline RESPONSE & FREQUENCY DISTRIBUTION & PERCENTAGES \\
\hline Yes & 9 & 42.9 \\
\hline No & 11 & 52.4 \\
\hline & 21 & 100 \\
\hline
\end{tabular}

This means 11 head teachers do not have the required number of teacher that is 11 of them representing $52.4 \%$ and only 9 heads say that they have the required number which $42.9 \%$. According to this question the ministry of education in Manga Sub-county has to deploy more teachers in those schools that do not have the required number so as to release better results in the near future.

\section{How many teachers are in your school}

This question was asked to pupils to indicate number of teachers at each school has as shown below in the table;

\begin{tabular}{|l|l|l|}
\hline NUMBER OF TEACHERS & FREQUENCY DISTRIBUTION & PERCENTAGES \\
\hline 8 & 92 & 24.1 \\
\hline 9 & 40 & 10.5 \\
\hline 10 & 47 & 12.3 \\
\hline 11 & 41 & 10.8 \\
\hline 12 & 36 & 9.4 \\
\hline 13 & 14 & 3.7 \\
\hline 18 & 108 & 28.3 \\
\hline & 381 & 100 \\
\hline
\end{tabular}

This means that across the Sub-county of Manga most the schools have 18 teachers that $28.3 \%$ suggesting that the number of teachers is good, others have 8,9 and 10 teachers which is still a good number thus no doubt 
in the performance of the pupils, but still those schools that think they don't have the best number then let them increase the number of teachers so as to perform well. The average number of teachers in the schools is 11

\section{Conclusion}

The study revealed that the average number of teachers in schools in Manga is 11 with minimum being 3 and maximum being 18 teachers. The average number of students is 235 with minimum being 125 and maximum 687. The number of classrooms range from minumu of 3 and maximum of 18 . Tmost schools do not have adequate space for expansion, pit latrines, connection to electricity, water sources and points, curriculum materials and writing materials this was said as the reason for low academic performance.

\section{REFERENCES}

Chabari, E.B (2010). Challenges Facing Effective Implementation of Secondary Education in public secondary schools in Kangundo district, Kenya: Unpublished MED Thesis, Chuka: Chuka University College..

Gulati, S. (2008). Technology-Enhanced Learning in Developing Nations: University of Oxford, U.K.

Koech,P.L. (2006). Influence of Gender Stereotype on Girls and Performance in mathematics in secondary schools in Butere-Mumias district. Unpublished M.Phil.thesis, Moi University, Eldoret,Kenya.

Ngware M.W (2007) Financing Education in Kenya; cost Reduction and Financing Options, Nairobi..

Republic of Kenya, (1988). Sessional Paper No. 6 of 1988. Education and Manpower Training for the Next Decate and Beyond. Nairobi, Government Printers

Republic of Kenya, (2005). Kenya Education Sector Support Programme (KESSP): Delivering Quality Education \& Training to All Kenyans. Nairobi, Government of Printers.

Republic of Kenya, (2011). Report of the Task Force in Re-Alignment of Education Sector to the Constitution. Nairobi, Government Printer.

Republic of Kenya, (2012). Sessional Paper No. 1 of 2005 on a Policy Framework for Education, training and Research. Nairobi: Government Printer.

Republic of Kenya, (2012). Sessional Paper no ....... Of 2012. A policy Framework for Education and Training, reforming Education and Training in Kenya. Nairobi: Government Printer.

Thomas, R. \& Dreeben (1980).TheAnalysis of Educational Productivity. Volume1: Issues in Microanalysis.Cambridge, Berlinger Publishing.

UNESCO (2005).EFA; The Quality Imperative; 2005; Monitoring Report. Paris EFA Secretariat.

UNESCO, (2006). EFA. Global Monitoring Report the Role of the Organization and Social Context of Schools. Abdicating of United Nations. (1968). Declaration of Human Rights. New York: United Nations. 